\title{
Food Security: Results of Russian Embargo on Poultry Meat Import
}

\author{
Vladimir G. Svinukhov ${ }^{1}$, Marina $V$. Konysheva ${ }^{2 *}$ and Irina $G$. Makarova $^{1}$ \\ ${ }^{1}$ Plekhanov Russian University of Economics, Moscow, Russian Federation \\ ${ }^{2}$ Russian University of Transport (RUT-MIIT), Law Institute, Moscow, Russian Federation
}

\begin{abstract}
The paper presents a geographically based assessment of the volume and value of imported poultry meat into the Russian Federation under the embargo restrictions. The assessment is based on the foreign trade statistics issued by the Customs Service of the Russian Federation. In volume terms, the import of poultry meat to the Russian Federation in 2015 decreased by $14 \%$ as compared to the volume of 2014; in value terms it decreased by $6 \%$. The geography of the import also changed. Before the embargo, the main suppliers of poultry meat to the Russian Federation were the USA (51\%), Belarus (16\%) and Brazil (10\%). After the embargo was introduced, the United States (30\%) still remained the main supplier along with Brazil (21\%). A significant market share of poultry meat supplies to the Russian Federation was captured by Belarus (26\%). Keywords - meat products, poultry meat, customs duty, trade embargo, import duties, customs fees.
\end{abstract}

\section{Introduction}

Economic sanctions against a commercial competitor are not a present-day discovery. They came into practice as early as in the ancient world to compel rivals and potential enemies to comply with the rules or obligations imposed on them by the economically stronger party. Thus, about 2500 years ago, with the idea to force a neighboring town Megara into submission, Athens declared a trade embargo against its community, which ended in the Peloponnesian War. Though sanctions often proved to be ineffective and turned into their opposite they have been used in trade relations for centuries so far.

The Russian Federation in its modern state, like the USSR as its predecessor, has always lived and developed under some sanctions which have been introduced against it in the form of engineering know how and technology embargoes, high-tech industry restrictions, suspended credit finance, asset freezes and even visa bans on some prominent Russian businessmen and powerful officials [1, $\mathrm{p}$. $15]$.

Whatever political or financial reasoning is given to justify economic embargo against some country or countries, the real purpose of most sanctions is to take advantage over the economic competitor and secure commercial benefits for the economically dominant country, which introduces them and resorts to any unscrupulous means supposable to keep its leading position [2, p. 162].

Long before the political crisis of 2014 in Ukraine, the US adopted the so-called "Magnitsky Act" that almost immediately followed the suspension of Jackson-Vanik Amendment to the Trade Act of 1974.
The law, which prompted an angry reaction from Russian people and Russian President Vladimir Putin, at first blocked 18 Russian government officials and businessmen from entering the US along with the freezing of assets, restrictions on financial dealings with certain named entities, operating in the Russian financial capital markets, restrictions on the export or sale of certain dual-use goods and technologies and etc.

Since then the US have expanded sanctions against the Russian Federation many times and involved the European Union into the sanctions war on their side. At the same time in Russia, economic sanctions are perceived as a blessing in disguise. Though they have affected the economy and slowed down the economic growth, they gave a push to review the structural character of the national economy. In economic terms Russia has found ways to fill the financial and technological gap and has become more self-sufficient than it had been before the US started to bombard it with economic restrictions [3, p. 14].

There is no doubt that the main reason for which the US undertook such unfair measures for a growing competitor is Russia's independent world policy and noticeable attempts to regain the role of a world leader in the sphere of world politics, if not in global trade or economy yet.

Russia did not take long to respond to the unfriendly economic steps from the US and EU countries, which always act in the wake of the American global policy, and launched a string of sanctions against them. Among the potential measures, Russia chose the less painful for itself and the most damaging for those countries, which initiated sanctions. It appeared to be a ban on agricultural products, raw materials and food, traditionally imported by Russian retail chains from the US, EU countries and the countries 
that joined them in the sanctions policy against Russia. As it is specified in the Presidential executive order of August 6, 2014 No. 560 "On Special Economic Measures to Protect the Russian Federation's Security", the Government of the Russian Federation was instructed to ensure within its authority the fulfilment of measures to implement the Executive Order and imposed a ban on import to the Russian Federation of agricultural production, raw materials and food.

The list of banned agricultural production includes: milk and dairy products, vegetables, edible roots and tubers, fish and crustaceans, mollusks and other aquatic invertebrates as well as finished products, including cheese and curd (cottage cheese), based on vegetable fats, meat and meat products.

These types of food products, raw or processed, are prohibited for import into the territory of the Russian Federation if they are grown or by other means are produced in EU countries, the U.S., Australia, or other countries that joined the economic sanctions against the Russian Federation.

Banned meat products of EU countries' origin make a considerable part of the Russian Federation agricultural export embargo, introduced by the RF government in response to Western sanctions, which were annually extended after 2014 (table 1).

Table 1. Meat products banned for import to the Russian Federation

\begin{tabular}{|l|l|}
\hline $\begin{array}{c}\text { HS } \\
\text { Code }\end{array}$ & \multicolumn{1}{c|}{ Product name } \\
\hline 0201 & Meat of bovine animals, fresh or chilled \\
\hline 0202 & Meat of bovine animals, frozen \\
\hline 0203 & Pork, fresh, chilled or frozen \\
\hline 0207 & $\begin{array}{l}\text { Meat and edible offal of the poultry indicated in line } \\
\text { 0105, fresh, chilled or frozen out of 0210** Meat } \\
\text { salted, in brine, dried or smoked }\end{array}$ \\
\hline 16010 & $\begin{array}{l}\text { Sausages and similar products of meat, meat offal or } \\
\text { blood; final food products based thereon }\end{array}$ \\
\hline
\end{tabular}

A list of agricultural produce, raw materials and food products, which producer is the United States of America, the European Union countries, Canada, Australia and the Kingdom of Norway, and which are banned for import into Russia for a period of one year includes: meat of bovine animals (HS Code 0201-0202), pork (HS Code 0203), meat and edible offal of the poultry (HS Code 0207), as well as sausages and similar products of meat, meat offal or blood; final food products based thereon (HS Code 160100) [4, p. 160].

Can import ban for goods of HS Code 0207, imposed by the Russian Federation, have a negative impact on the market? There is no denying the fact, that the ban has somehow limited the choice of products on the domestic market, but, on the other hand, it has given a strong impetus to the development of agricultural sector of the Russian economy.

Latest data prove that after 2014 the Russian agricultural sector showed a notable boom. Today farming takes more than half of Russia's agricultural sector, 80 percent of which is grain production. Grain, especially wheat, is not only a significant crop and an important component of Russia's food supply, it is a base for breeding domestic animals and raising poultry. While over $2 / 3$ of the wheat grown in Russia is consumed domestically, Russia still covers $10.5 \%$ of the world's wheat exports.

The result of the research study given below demonstrates the value of imported goods (HS Code 0207) over the past few years. The study is based on the geographical origin of the commodity and customs payments into the budget.

\section{Materials, methods and organization of research}

The study of the market shows that the poultry segment in Russian Federation is less dependent on imported production. In 2013 the import share in the total amount of consumption of this product was about 13\%, and in 2014 it dropped to $9 \%$ (table 2).

Table 2. Key market indicators at the end of 2014.

\begin{tabular}{|c|c|c|c|c|}
\hline Year & $\begin{array}{c}\text { Volume of } \\
\text { production } \\
\text { in slaughter } \\
\text { weight } \\
\text { (thousand } \\
\text { metric tons } \\
\text { (MMT) }\end{array}$ & $\begin{array}{c}\text { Volume } \\
\text { of } \\
\text { import } \\
\text { (thousa } \\
\text { nd } \\
\text { metric } \\
\text { tons) }\end{array}$ & $\begin{array}{c}\text { Volume } \\
\text { of tariff } \\
\text { quotas } \\
\text { thousand } \\
\text { metric } \\
\text { tons) }\end{array}$ & $\begin{array}{c}\text { Import } \\
\text { ratio of } \\
\text { the total } \\
\text { market } \\
\text { capacity } \\
(\%)\end{array}$ \\
\hline 2013 & 3790 & 527 & 364 & 12.21 \\
\hline 2014 & 4424 & 452.5 & 364 & 9.28 \\
\hline
\end{tabular}

For many years, the main supplier of poultry to the Russian Federation was the USA. Following the results of $2013,50.5 \%$ (266 thousand tons) of all the poultry imported to Russia came from the USA. Following the results of 2014, the USA share was only $30.4 \%$ (138 thousand tons). The production potential of this sector of production continued to grow in the Russian Federation from year to year [3, p. 16].

The federal programme of substitution for the banned food products turned out to be most efficient in meat sector. From January to September 2014, Russian poultry farms increased the production of poultry meat by nearly $9.3 \%$ year-on-year [5, p. 58]. In September 2014, the production of poultry meat and offal in Russia increased by $2.9 \%$ in comparison with the previous month, and by $12.6 \%$ compared to September 2013. Taking into account the fact, that prices for poultry meat were constantly rising (food prices grew by 14.7 percent in 2014), the margin in poultry production sector of economy was at its highest level at the end of 2014. It gave an additional impetus for poultry enterprises to enlarge production of poultry meat and edible offal of the poultry [6, p. 90].

Despite the economic slowdown (economic growth in 2014 showed 0.6 percent compared to 1.3 percent in 2013), domestic agricultural production on the whole and poultry meat in particular, revealed potential leverages, which came into force in comparatively favorable circumstances. Among them, one should mention large targeted loans from the federal budget, financing of enterprises at the pre-production 
stage, special measures to stimulate import substitution through governmental or municipal procurement [7, p. 383].

Though scrupulously calculated and targeted, the retaliatory sanctions, implemented by Russia, still buried in themselves hidden risks, as Russia was and still remains one of the world's largest food-importing countries. In the years prior to the political crisis of 2014, followed by sanctions on both parts, Russian food processing companies and retail chains used to import approximately $70 \%$ or, according to some assessments, over $70 \%$ of foodstuff agricultural products, beverages, raw materials for manufacturing food products and etc. The total amount of money paid for it in some years equaled or even exceeded $\$ 40$ billion [8, p.7317].

It was a highly challenging commission to start looking for alternative foreign suppliers and initiate import substitution for the foods, which can be produced in the country. Severe climatic conditions in most Russian regions will never allow Russian farmers to practice outdoor growing of oranges or pineapples, but it is possible to change producers, if some of them start playing political games on Russia. Thus fruit and vegetables, that before 2014 used to be imported from EU countries, started to be purchased from Turkey, the Middle East countries and countries of South-East Asia.

The case with poultry meat and by-products came to be more foreseeable for several reasons - a short life cycle of broilers (just six weeks, or 42 days), obtainable feeding stuff and a long-standing tradition of growing poultry in family households. Nowadays family households grow poultry and livestock mainly for their personal needs, while big chicken factory farms have substituted farm units typical for the Russian countryside nationwide. Growing poultry on such chicken farms has turned into a very dynamic business since a new technology of breeding was widely introduced into practice. Modern innovative engineering offers high-tech automation and machines, which make the process of growing poultry very similar to a production line in a large car factory.

As a result, the way from the chicken farm to the consumer has become considerably short, for that reason the poultry meat production has become highly profitable and attracted good investments into it. This explains why and how poultry production started to extend far beyond traditional agriculturally successful regions as Stavropol, Belgorod, Volgograd and Kursk, located in comparatively favourable climatic areas with mild winters and fairly warm summers, to less fortunate territories, which belong to the so-called zones of risky agriculture, as Omsk or the Republic of Bashkortostan. Besides being highly profitable for the owners, modern chicken farms, scattered over the vast territory of the Russian Federation, help to diversify systemic risk in this sector of farming.

Import substitution and the development of domestic agricultural production were declared as a national priority by the Russian Government almost immediately after the ban on agricultural production grown in EU countries, the US and some other countries. This strategy proved its value in the first year of reciprocal sanctions and Russia managed to produce $70 \%$ of the poultry meat market demand by the end of 2014 [9, p. 270].
The study of the poultry production volume in Russia shows that the small deficit of the market demand was covered by the deliveries from the Republic of Belarus and Brazil. Following the results of 2013, the share of the poultry meat from Brazil covered 10\% (54 thousand tons) of all deliveries of this production to Russia, and in 2014, it amounted to $26.5 \%$ (120 thousand tons). In 2014 poultry meat deliveries to Russia decreased by $14 \%$ in real volume and by $6 \%$ in value as compared with the deliveries in 2013. It should be noted that the main producers and exporters of poultry meat in the world were the USA, Brazil and the EU countries (table 3).

Table 3. The world output, import and export of the poultry among the leading countries following the results of 2014.

\begin{tabular}{|c|c|c|c|c|c|}
\hline \multicolumn{4}{|c|}{ Poultry meat } \\
$\begin{array}{c}\text { Production } \\
\text { (million metric } \\
\text { tons) }\end{array}$ & \multicolumn{2}{c|}{$\begin{array}{c}\text { Import (million } \\
\text { metric tons) }\end{array}$} & \multicolumn{2}{c|}{$\begin{array}{c}\text { Export } \\
\text { million metric } \\
\text { tons) }\end{array}$} \\
\hline USA & 16.976 & Japan & 0.854 & Brazil & 3.482 \\
\hline China & 13.350 & $\begin{array}{c}\text { Saudi } \\
\text { Arabia }\end{array}$ & 0.82 & USA & 3.340 \\
\hline Brazil & 12.308 & Iran & 0.673 & EU & 1.083 \\
\hline EU & 9.800 & EU & 0.671 & $\begin{array}{c}\text { Thailan } \\
\text { d }\end{array}$ & 0.362 \\
\hline India & 3.450 & Mexico & 0.682 & Turkey & 0.362 \\
\hline Russia & 3.790 & Russia & 0.54 & China & 0.420 \\
\hline Mexico & 3.002 & Angola & 0.321 & $\begin{array}{c}\text { Argenti } \\
\text { na }\end{array}$ & 0.324 \\
\hline other & 21.397 & other & 4296 & other & 0.722 \\
\hline Total & $\mathbf{1 6 . 9 7 6}$ & Total & $\mathbf{8 . 8 5 7}$ & Total & $\mathbf{1 0 . 2 3}$ \\
\hline
\end{tabular}

Source: Ministry of Agriculture of the USA

\section{Results and their consideration}

It can be expected that various factors may affect the import of poultry meat to Russia, among them: 1) business cyclic fluctuations, 2) ban for the imported poultry meat, 3) drop in the value of the country's currency and, as a result, a rise in price of products of foreign origin [10, p. 89].

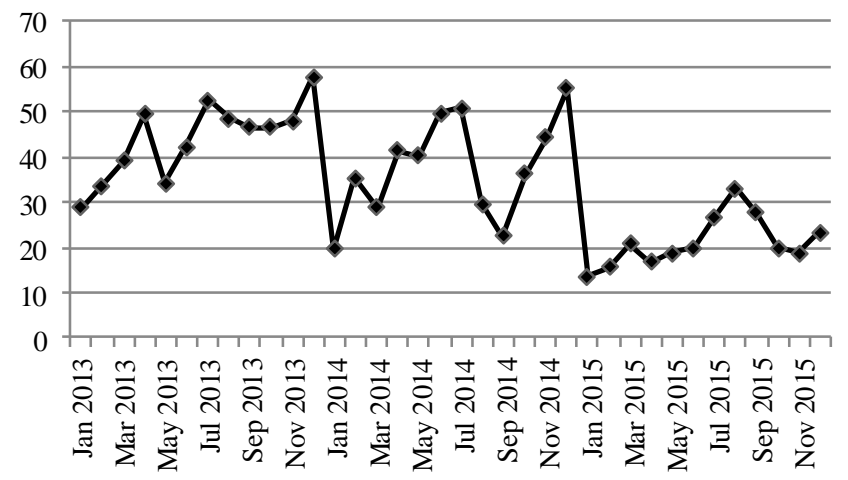

Fig. 1. Poultry meat imported to the Russian Federation in products category code 0207 ( $\mathrm{mln}$ \$ US). Data issued by the RF Customs Service statistics 2013-2015.

Source: Russian Federation Customs Service Statistics 2014-2015.

To assess business cyclic fluctuations let us study import volumes in value terms of goods HS Code 0207 from 
January 2013 to March 2015 (graph 1). Below is the graphical representation of Russia poultry imports drawn by month.

The data, represented in the graph, demonstrate that the commodity group of HS Code 0207 are imported with a certain cyclical recurrence. December witnessed the maximum value of deliveries, and January - its minimum. It is necessary to point out that the maximum value of imported poultry meat in 2014 exceeded the maximum of the 2013 by $12.2 \%$. Meanwhile the January minimum of 2014 and 2015 correspond as follows. In January 2014, deliveries of commodity group HS Code 0207 decreased in value by half in comparison with January 2015.

In modern world economy customs and tariff regulation functions, on the one hand, as the effective regulator, promoting greater openness of markets to import, on the other - as the most widespread foreign trade instrument of protectionism.

Customs and tariff regulation covers the entire world commodity turnover. At the same time, over the recent decades, a steady decrease in rates of import customs duties is observed. Today, the average level of such duties in economically developed country members of the WTO makes $4-6 \%$ while, at the time GATT-WTO was established, it exceeded $30 \%$ [11, p. 47].

Nowadays customs and tariff regulation is becoming not only a tool of the general economic policy at the national level, but also an object of the regulatory activity of international economic organizations, first of all, of the WTO. The WTO aims to develop general principles, norms, rules and instruments of customs and tariff regulation with the purpose to minimize obstacles for the development of international trade, so that "trade flows as smoothly, predictably and freely as possible".

Russia has been developing legal and economic bases of modern customs and tariff regulation of the foreign trade activity since the beginning of the 90 s, and now in general they meet the standards and rules of the WTO.

For Russia, the fiscal function of the customs tariff regulation is most crucial. While in economically developed countries the budget income from customs receipts makes a small share of the revenues (e.g., in the USA it makes no more than $1.5 \%$ ), in the Russian budget of 2013-2014 it made $50-52 \%$ of all revenues.

For the assessment of the budget revenues which come from customs receipts, the study presents the average value of the ad valorem rate of the import tariff for some product positions as they are set in the Eurasian Economic Union (EAEU), as well as a share of each commodity position into customs payments.

The average value of the ad valorem rate for $\mathrm{j}$ - HS Code position was calculated using the formula [12, p. 97]:

$$
\overline{X_{j}}=\frac{\sum_{i-1}^{n} x_{i j}}{n_{j}} \quad j=1,2, \ldots, n \text {, }
$$

in which $x_{i j}$ stands for data value, $i$ - for rate of duty, $j-$ for HS Code category of the import customs tariff, $n_{j}-$ for the number of customs rate in $j$, which stands for the position of the import customs tariff.
Product of average ad valorem rate by the corresponding value reflects the amount of customs payments, which come from the customs tariff on the commodity categories, that is:

$$
Y_{j}=\bar{X}_{j} D_{j}
$$

in which $D_{j}$ is the total cost of the goods from category $j$ of the HS Code, moved across the customs border.

The united input of customs payments into the state budget is obtained by the proportion:

$$
Y=\sum_{j=1}^{n} Y_{j}
$$

Pro rata contribution from customs duty payments into the corresponding section of the customs import tariff code/book is calculated by the formula:

$$
\grave{A}_{j}=\frac{\bar{X}_{j} * D_{j}}{\sum_{i=1}^{n} Y_{j}} * 100 \% \quad(i=1,2, \ldots \mathrm{n}) \text {. }
$$

Common external tariff of the Eurasian Economic Union and the common commodity nomenclature of foreign economic activity are applied on the common territory of the EAEU and are the instruments of trade policy.

Before estimating receipts from customs payments, it is important to note that for the goods, imported to the customs territory of the Eurasian Economic Union (the EAEU) Member States, tariff privileges can be applied in the form of exemption or reduced rates of import customs duties. The Eurasian Economic Union, established by the Russian Federation, the Republic of Belarus and the Republic of Kazakhstan, declares free trade regime for the member countries on the territory of the EAEU and stipulates tariff preferences on some categories of goods for developing and (or) least developed countries.

Meanwhile the EAEU specifies the rules to protect the internal market; establishes requirements for labeling the origin of goods; stipulates the implementation of government (municipal) procurement; demands recording statistics of foreign trade; defines the rules for determination of the origin of goods imported into the customs territory of the EAEU.

Tariff privileges can't bear individual character and are provided regardless of the country of goods' origin, which distinguishes them from tariff preferences.

Thus, the customs duty set by the Customs Tariff at the rate of 0.75 is applied to the goods imported from economically developing countries, such as Brazil, Paraguay, Uruguay, Argentina. The rate of the customs duty at $0 \%$ is applied to the goods imported from the territory of the CIS countries. The base rate of tariff of EAEU member countries is applied to the goods imported from economically developed countries [13, p. 170].

To estimate the effect of the import ban, introduced in August 2014, it is worthwhile to correlate the cost of the imported goods (duty payments) by July 2014. Such analysis shows that the cost of the imported goods and 
customs payments for the commodities of HS 0207 position dropped 5.2 times lower by March 2015.

Table 4 represents value, weight and customs payments from imported poultry meat HS Code 0207. In 2013 81.0 \% HS Code 0207 of all meat was imported from six countries - the USA, Brazil, Belarus, Ukraine, France, Poland.

Table 4. Exporting countries, value of imported goods, (mln US \$), weight (kg), customs payments (mln US \$), in code category 0207.

\begin{tabular}{|c|c|c|c|c|}
\hline 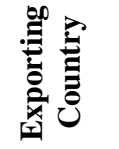 & 总总合 & 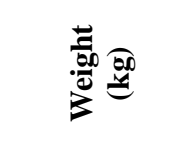 & 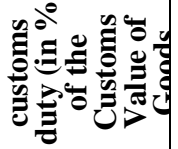 & 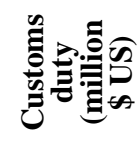 \\
\hline USA & 337.6 & 266475913.5 & $\begin{array}{c}25 \% \text { of } \\
\mathrm{CV}, \text { but } \\
\text { no less } \\
\text { than } € \\
0.2 / 1 \mathrm{~kg}\end{array}$ & $84.4 / 53.3$ \\
\hline Belarus & 170.2 & 81965783.6 & $0 \%$ of $\mathrm{CV}$ & 0 \\
\hline Brazil & 147.5 & 54277016.5 & $\begin{array}{c}25 \% \text { of } \\
\mathrm{CV}, \text { but } \\
\text { no less } \\
\text { than } € 0.2 \\
/ 1 \mathrm{~kg} \\
(* 0.75)\end{array}$ & $27.7 / 8.4$ \\
\hline Ukraine & 73.8 & 39539887.7 & $0 \%$ of $\mathrm{CV}$ & 0 \\
\hline France & 22.9 & 18407205.7 & $\begin{array}{c}25 \% \text { of } \\
\mathrm{CV}, \text { but } \\
\text { no less } \\
\text { than } € \\
0.2 / 1 \mathrm{~kg} \\
(* 0.75)\end{array}$ & $5.7 / 3.7$ \\
\hline Poland & 11.2 & 9854996.5 & $\begin{array}{c}25 \% \text { of } \\
\mathrm{CV}, \text { but } \\
\text { no less } \\
\text { than } € \\
0.2 / 1 \mathrm{~kg} \\
(* 0.75)\end{array}$ & $2.8 / 2.0$ \\
\hline
\end{tabular}

Source: the Russian Federation Customs Service Statistics for 2014-2015. Calculations are made by the authors.

The customs duty paid by these countries when importing goods equaled 120.1 million US dollars while it reached about 151 million US dollars on all commodity position. At the same time, it is significant to estimate the cost of deliveries from different countries. Calculations prove that the cost of $1 \mathrm{~kg}$ of the imported poultry meat equaled 1.27 US dollars when delivered from the USA, 2.72 US dollars from Brazil, 2.08 US dollars from Belarus, 1.87 US dollars from Ukraine, 1.24 US dollars from France, 1.13 US dollars from Poland.

In 2014 six counties - the USA, Brazil, Belarus, Argentina, Turkey, the Netherlands - supplied to Russia 89.2 $\%$ of all imported poultry meat (HS 0207). Table 5 specifies the imported poultry meat from the mentioned above countries evaluated in volume, weight, value and rate of customs duty.

The customs duty paid by these countries on the goods supplied to Russia amounted to 107.1 million US dollars while it reached about 140 million dollars on all commodity position. This makes it possible to state the $6 \%$ decrease in payments on the commodity position HS 0207 . At the same time, the cost of $1 \mathrm{~kg}$ of the imported poultry meat equaled
1.19 US dollars when delivered from the USA, 2.27 US dollars from Brazil, 2.32 US dollars from Belarus, 1.57 US dollars from Argentina, 1.40 US dollars from Turkey, 1.24 US dollars from the Netherlands.

Table 5. Exporting countries, value of imported goods (mln US \$), weight (kg), Customs duty (mln US \$), in categories 0207, 2014.

\begin{tabular}{|c|c|c|c|c|}
\hline 象易 & 总总合 & 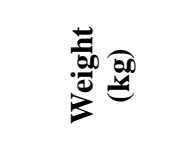 & 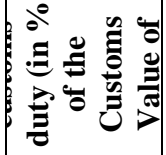 & 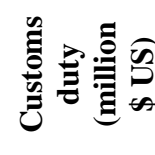 \\
\hline USA & 164.0 & 137712898.6 & $\begin{array}{c}25 \% \text { of } \\
\mathrm{CV}, \text { but } \\
\text { no less } \\
\text { than } € \\
0.2 / 1 \mathrm{~kg}\end{array}$ & $41.0 / 27.5$ \\
\hline Brazil & 272.7 & 120331435.0 & $\begin{array}{c}25 \% \text { of } \\
\mathrm{CV}, \text { but } \\
\text { no less } \\
\text { than } 0.2 \\
\text { euro/ } 1 \\
\mathrm{~kg} \\
(* 0.75)\end{array}$ & $51.1 / 18.0$ \\
\hline Belarus & 215.6 & 93122696.9 & $\begin{array}{c}0 \% \text { of } \\
\mathrm{CV}\end{array}$ & 0 \\
\hline Argentina & 34.2 & 21698875.1 & $\begin{array}{c}25 \% \text { of } \\
\mathrm{CV}, \text { but } \\
\text { no less } \\
\text { than } € \\
0.2 / 1 \mathrm{~kg} \\
(* 0.75) \\
\text { of } \mathrm{CV}\end{array}$ & $6.4 / 3.3$ \\
\hline Turkey & 26.3 & 18739616.4 & $\begin{array}{c}25 \% \text { of } \\
\mathrm{CV}, \text { but } \\
\text { no less } \\
\text { than } € \\
0.2 / 1 \mathrm{~kg} \\
(* 0.75)\end{array}$ & $4.9 / 2.8$ \\
\hline Netherlands & 14.9 & 11974704.8 & $\begin{array}{c}25 \% \text { of } \\
\mathrm{CV}, \text { but } \\
\text { no less } \\
\text { than } 0.2 \\
€ / 1 \mathrm{~kg}\end{array}$ & $3.7 / 2.4$ \\
\hline
\end{tabular}

Source: Russian Federation Customs Service Statistics for 2014-2015. Calculations are made by the authors.

\section{Conclusion}

The study described above makes it possible to estimate the impact of the ban on import of poultry meat to the Russian Federation imposed by the Presidential executive order of August 6, 2014 No. 560 "On Special Economic Measures to Protect the Russian Federation's Security".

In physical terms real volumes of deliveries decreased by $14 \%$, in value terms by $6 \%$. The geography of the product suppliers changed. If the main suppliers of poultry meat to Russia in 2013 were the USA $(51 \%)$, Belarus $(16 \%)$ and Brazil (10\%); in 2014 the main suppliers remained but with the different share of the market - USA (30\%), Belarus (26\%), Brazil (21\%).

The customs duty paid by these countries on the goods, supplied to Russia, amounted to 107.1 million US dollars 
while it reached about 140 million dollars on all commodity position. This makes it possible to state the $6 \%$ decrease in payments on the commodity position HS 0207. At the same time, the cost of $1 \mathrm{~kg}$ of the imported poultry meat equaled 1.19 US dollars when delivered from the USA, 2.27 US dollars from Brazil, 2.32 US dollars from Belarus, 1.57 US dollars from Argentina, 1.40 US dollars from Turkey, 1.24 US dollars from the Netherlands.

Summing up the results of the study, there is no denying the fact that the Russian Federation has managed to restructure the sources of meat import, as well effectively support domestic producers. The agricultural import embargo had a positive effect on the Russian agricultural sector of economy as it was used as a protectionist measure, which boosted small farming businesses in Russia along with the governmental program of cheap loans.

Today, it can be said that the food embargo even contributed to the growth of the popularity of Russian products among the Russian people, gave rise to greenhouses business and agricultural corporations, making Russia more self-sufficient and independent on food imports. However the potential of the poultry meat production in Russia is not exceeded yet. Together with providing for domestic consumption needs, Russia has increased poultry meat export considerably. Experts predict the steady growth in the demand for animal products on the world market and expect it to exceed $45 \%$ within a period of 2010-2030. Here Russia has a good opportunity to enter foreign markets, especially in the countries with the fast growing population, like Azerbaijan, Vietnam, China, the UAE, and Iran. Though audits were already fulfilled by the authorities of these countries, much is left to be done to bring poultry meat production in Russia to maximum compliance with the international requirements.

As the Russian Federation has prolonged embargo of EU food products to the end of 2018, it gives Russian producers a good opportunity to pay off the loans they took in previous years, make profit, and produce new volumes of food without much risk of losing their market share. Alexander Tkachev, the Russian minister of agriculture, went to even greater lengths in an interview to the TASS news agency expressing his hope, that food embargo will not be limited to 2018, but remain in force at least until 2020.

\section{References}

1. P.E. Votes, V.I. Gorelov, A.I. Fedoseev, O.L. Krylova, Trends in the development of science and education 16-2, pp. 13-22 (2016)

2. M.V. Konysheva, Materials of the International Scientific Conference on "Import substitution policy and development of non-recourse export as the priority of today's industrial policy of Russian Federation. Conference proceedings" (Plekhanov Russian University of Economics, Moscow, 2016)

3. E.V. Vavilova, Bulletin of the Russian state University of trade and Economics (RGTEU) 11-12, 12-19 (2013)

4. G.Yu. Gagarina, L.S. Arkhipova, A.I. Gretchenko, etc. Foundations of economic security. (Moscow, 2017)

5. V.A. Vernikov, MIR 6(2-2 (22)), 54-60 (2015)
6. V.S. Berchenko, T.A. Voronova, E. V. Permyakov, etc. The strategic interests of Russia in the global economy. (Moscow, 2015)

7. O.G. Demenko, I.G. Makarova, M.V., Konysheva, Man in India 97(20), 381-390 (2017)

8. N.A. Moiseev, S.V. Manakhov, O.G. Demenko, International Journal of Applied Business and Economic Research 14(10), 7315-7324 (2016)

9. B. Akhmadeev, S. Manakhov, Journal of Security and Sustainability Issues 5(2), 269-284 (2015)

10. S. A Ermolaev, E. V. Zaitseva, P. I. Komarov and others, Analytical notes. Situational socio-economic development of regions. Moscow 4, 132 (2015)

11. E. V. Trokhova, Economics and entrepreneurship 3-1 (80-1), 46-49 (2017)

12. S.V. Senotrusova, V.G. Svinukhov, E.V. Vavilova, I.G. Makarova, O.G. Demenko, WSEAS Transactions on Business and Economics 15, 93-98, (2018)

13. N.A. Moiseev, S.V. Monks, O.G. Demchenko, Bulletin of the Russian University of Economics. G. V. Plekhanov 2(92), 169-177, (2017) 